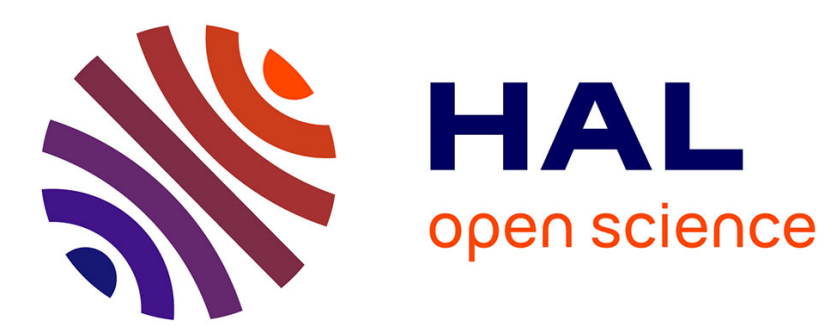

\title{
Capital Flow Bonanzas and Monetary Policy in Emerging Europe: Responses to the Global Financial Crisis
}

Jean-Pierre Allegret, Audrey Allegret-Sallenave

\section{- To cite this version:}

Jean-Pierre Allegret, Audrey Allegret-Sallenave. Capital Flow Bonanzas and Monetary Policy in Emerging Europe: Responses to the Global Financial Crisis. Post-Communist Economies, 2015, 27 (4), pp.429- 447. hal-01385959

\section{HAL Id: hal-01385959 \\ https://hal.parisnanterre.fr/hal-01385959}

Submitted on 16 May 2018

HAL is a multi-disciplinary open access archive for the deposit and dissemination of scientific research documents, whether they are published or not. The documents may come from teaching and research institutions in France or abroad, or from public or private research centers.
L'archive ouverte pluridisciplinaire HAL, est destinée au dépôt et à la diffusion de documents scientifiques de niveau recherche, publiés ou non, émanant des établissements d'enseignement et de recherche français ou étrangers, des laboratoires publics ou privés. 


\title{
Capital Flow Bonanzas and Monetary Policy in Emerging Europe: Responses to the Global Financial Crisis
}

\section{Jean-Pierre Allegret}

EconomiX, UMR 7235 CNRS and University Paris Ouest Nanterre La Défense, France. Email: jallegret@u-paris10.fr. Mail address: University Paris Ouest Nanterre La Défense, EconomiX, Building G, 200 avenue de la République, 92001 Nanterre Cedex France. Corresponding author.

\section{Audrey Sallenave}

LEAD, University of Toulon, France and EconomiX, UMR 7235 CNRS and University Paris Ouest Nanterre La Défense. Email: audrey@sallenave.fr. Mail address: 70, Avenue Roger Devoucoux 83000 Toulon, France

\begin{abstract}
We analyze the conduct of monetary policy in some new member states of the EU and some EU candidates over the period 2000-2013. We investigate why monetary policy has been ineffective to insulate domestic liquidity from capital inflows and why some countries from emerging Europe have been especially constrained to respond to the crisis. Our contribution is threefold. First we show that countries with fixed exchange rate regimes have encountered significant obstacles to conduct monetary policy to cope with large capital inflows and credit booms during the period preceding the financial crisis. Second we shed in light that pegged countries have been more constrained to respond to the global financial crisis than nonpegged economies. Third, countries with high currency mismatch and financial vulnerabilities seem unable to adopt monetary policy dedicated only to macroeconomic stabilization.
\end{abstract}

Keywords: capital flows, emerging European countries, financial crisis, monetary policy

JEL Codes: E4, E5, F3, P3 


\section{Introduction}

This paper tends to analyze the conduct of monetary policy in some new member states of the European Union (EU thereafter) and some EU candidates over the period 2000-2013. More specifically, we consider a sample of nine former transition economies: Bulgaria, Croatia, Estonia, Hungary, Latvia, Lithuania, Poland, Romania, and Serbia. All these countries have followed a pattern of domestic and external financial liberalization related to their accession process to the European Union. However, these countries differ in terms of exchange rate regimes adopted over the studied period. More specifically, a first group including Bulgaria, Croatia, Estonia, Latvia, and Lithuania adopted fixed regimes while a second group consisting of Hungary, Poland, Romania, and Serbia- followed floating regimes. ${ }^{1}$

The global financial crisis suggests that countries with more leveraged domestic financial system and more rapid growth in credit to the private sector exhibited more output losses than other economies (IMF, 2010; Berkmen et al., 2012). In addition, vulnerabilities to shocks increased when the credit boom was funded from abroad (CGFS, 2009). Such features characterize many countries in emerging Europe. Thus, our first aim is to investigate why monetary policy has been ineffective to insulate domestic liquidity from capital inflows.

The global financial crisis of 2008-09 had led to a renewed interest of the analysis concerning economic policies responses in emerging countries to financial crises (Ghosh et al., 2009, Vegh and Vuletin, 2012). While in previous episodes of financial crises, these economies tended to adopt procyclical monetary policy (Kaminsky et al., 2005), a growing number of studies have provided new empirical evidence according to which emerging economies tend to adopt counter-cyclical policies on a more regular basis. An interesting exception is emerging Europe (Josifidis et al., 2013 and 2014). Our second aim is to analyze why some countries from emerging Europe have been especially constrained to respond to the crisis.

A growing literature investigates the impact of the unconventional monetary policy ${ }^{2}$ followed by major central banks on international capital flows, and, more specifically, capital inflows into emerging countries (IMF, 2013). The third aim of this paper is to assess to what extent central banks from our studied countries can conduct an independent monetary policy. To this end, a panel regression with fix effects is estimated to identify the main factors influencing the determination of short term interest rate. We focus more particularly on the monetary policy framework adopted in the aftermath of the global financial and European sovereign debt crises in order to check for the spillovers effects resulting from the monetary policy adopted by the European Central Bank. 
The rest of this paper is structured as followed. Section 1 analyzes the accumulation of macroeconomic imbalances over the period 2000-2007. To this end, not only do we compare our sample to Latin American and South-Asian countries, but also we see to what extent floaters and fixers differ within our sample. Section 2 considers the responses of monetary policy during the global financial crisis. We explain why some European emerging countries had been especially constrained to a conduct counter-cyclical monetary policy. Section 3 investigates to what extent short term interest rates in our sample countries are influenced by other variables than domestic inflation and output as suggested in a standard Taylor rule. Section 4 concludes.

\section{The accumulation of macroeconomic imbalances before the Global financial crises}

Figure 1 suggests that Emerging Europe have particularly suffered from the 2008-2009 global financial crisis. Indeed, except Poland, all studied countries entered into recession and, above all, many of them experienced higher growth losses than both emerging developing countries and advanced economies. The figure also shows that recession had been deeper in countries with fixed exchange rate regimes (left side) than in countries with floating exchange rates (right side).

These different impacts of the Global financial crisis are in part explained by the macroeconomic imbalances accumulated over the period 2000-2007. Indeed, an extensive literature shows that initial conditions matter: countries that entered into the crisis with sizeable domestic and external imbalances have recorded more poor economic performances during the crisis (Lane and Milesi-Ferretti, 2011; Frankel and Saravelos, 2012).

\section{[Insert Figure 1]}

The aim of this section is to stress that countries with fixed exchange rate regimes encountered more difficulties to face macroeconomic imbalances than floaters.

\section{Domestic imbalances}

Figure 2 exhibits a feature that characterizes many crises episodes. Indeed, the positive output gap tends to increase just before the occurrence of the global crisis suggesting the presence of an unsustainable economic boom. ${ }^{3}$ Figure 2 has a second striking feature: the positive output gap tends to be higher for peggers than for floaters. 


\section{[Insert Figure 2]}

Monetary policy seems to have weakly reacted to the increasing positive output gap. In this perspective, the IMF (2008) has stressed that monetary policy conditions loosened in Emerging Europe before the Global financial crisis, particularly in the Baltics. Indeed, policy rates in this region tend to be lower than policy rates implied by the application of the Taylor rule by central banks. Figure 3 bears out this point by exhibiting the short term interest rates in real terms.

\section{[Insert Figure 3]}

Real short term interest rates are negative in many of our countries with fixed exchange rate regimes at the opposite to floaters suggesting the formers are constrained in terms of monetary policy to respond to the acceleration of growth rates.

Berkmen et al. (2012) investigate factors driving the growth performance in 2009 -measured by the revisions in GDP growth forecasts before and after the crisis- for a sample of 43 emerging markets. Their main finding is that countries with more leveraged domestic financial system and more rapid growth in credit to the private sector suffer from larger downward revisions of GDP forecasts. In addition, the IMF (2010) stresses that countries which experienced a pre-crisis credit boom underwent a dramatic output busts during the crisis.

The left side of figure 4 exhibits the credit growth in our sample, Latin America, and Asia. We see that Emerging Europe experienced rapid growth in their credit to the economy. The right side confirms - by considering the growth differential between credit and GDP- the extent of the credit boom in our studied countries. In addition, higher growth differentials are observed in economies with fixed exchange rate regime relative to floaters.

\section{[Insert Figure 4]}

\section{The increase in financial vulnerabilities}

Credit boom in Emerging Europe had been accompanied by an increase in financial vulnerabilities. Interestingly, figure 5, left side, shows that, in Emerging Europe, the growth in deposits has been insufficient to fund such credit growth. Indeed, the figure exhibits a striking increase in the loan-to-deposit ratio meaning that banks had to rely massively on other 
refinancing sources. The right side of figure 5 not only confirms the previous remark, but also portrays an interesting feature: the discrepancy between changes in deposit and credit to GDP had been especially sizeable in Emerging European countries with fixed exchange rate regimes.

These previous data are in line with Magud and Vesperoni (2014) who investigate how economies with different degrees of exchange rate flexibility behave during capital inflows reversals ${ }^{4}$. Their econometric estimates get two main results. On the one hand, a higher degree of exchange rate flexibility is accompanied by a lower domestic credit growth. On the other hand, countries with flexible exchange rates are less vulnerable to episodes of capital inflows reversals. Similarly, Bakker and Gulde (2010) noticed that credit booms experienced by some new EU member with fixed exchange rate regimes in emerging Europe in the 2000s have been difficult to contain.

\section{[Insert Figure 5]}

Financial vulnerability in Emerging Europe was considerably stronger relative to other emerging regions insofar as a significant part of the credit boom in this region had been funded from abroad. Figure 6 exhibits the rapid growth of assets of reporting banks vis-à-vis our sample countries from June 2006 to June 2008.

\section{[Insert Figure 6]}

Figure 7 suggests that the expansion of domestic credit had been fueled by foreign funds. This figure has an interesting feature. Indeed, focusing on our studied countries, we see that the relationship between consolidated foreign claims of BIS reporting banks and changes in domestic credit to private sector had been especially strong among peggers countries.

\section{[Insert Figure 7]}

Different motives can account for such behavior. First, lending interest rates tend to be lower in international financial centers while exchange rate risks seem low when authorities peg their currency against the dollar (Asian countries in the 90s') or the euro (Emerging Europe now) (Eichengreen and Hausmann, 1999). Second, currency mismatch may result from recurrent domestic instabilities that render uncertain the future value of the domestic currency. 
As a consequence, issuing debts in foreign currencies is easier (Mishkin, 1997). Finally, as stressed by Eichengreen et al (2007), emerging economies may be unable to borrow in their own currencies insofar as international investors are reluctant to diversify their portfolio i.e. to add currencies of developing countries, besides dollar, euro, yen, pound, and Switzerland franc. The important point is that this so-called "original sin" is not due to economic policies or institutional failures in emerging countries.

As a result, banks' balance sheets are vulnerable to any shock hitting the economy insofar as they suffer from an increasing currency mismatch, a situation in which economic agents have liabilities denominated in foreign currency while their assets are in domestic one (Kaminsky and Reinhart, 1999). Emerging countries with such mismatch are vulnerable to a sudden and large devaluation of their currency against the anchor one. Any devaluation increases the charge of the debt inducing a negative balance sheet effect.

Figure 8 shows that the currency mismatch increased in our sample countries -particularly in economies with fixed exchange rate regimes- while it tends to decline in Latin American South-Eastern countries. In this figure, we use as a proxy of currency mismatch the ratio foreign liabilities to money following the methodology of Levy-Yeyati et al. (2010).

\section{[Insert Figure 8]}

\section{The accumulation of external vulnerabilities}

On the external side, the global financial crisis in developed countries has led to a sharp reversal in capital flows (see below). As Emerging Europe accumulated large external deficits, while other emerging countries reduced their deficit or increased their surplus (figure 9, left side), Emerging Europe was particularly vulnerable to the financial channel. Indeed, current account deficits led Emerging Europe to be dependent on capital inflows to cover them, increasing their vulnerability to a sudden stop in capital flows. Interestingly, the right side of the figure shows that from 2005 peggers countries experienced larger deficits relative to floaters.

\section{[Insert Figure 9]}

The composition of net capital inflows in Emerging Europe exacerbates external vulnerability. Figure 10 compares the composition of these inflows in Emerging Europe with other emerging countries. The main lesson of this figure is the high weight of other private 
financial flows (including banking flows) in the former while in other emerging economies foreign direct investments prevail. However, an extensive literature shows that foreign direct investments are more resilient than other capital flows during crises.

\section{[Insert Figure 10]}

As stressed by Balakrishnan et al (2011), banking liabilities and portfolio exposures show that Emerging Europe was more vulnerable to external bank crises. In addition, Western European banks had increasingly dominated banking flows. As a result, Western Europe had become the most likely source of common-lender effects. Llaudes et al. (2010) and Gallego et al. (2010) find that pre-crisis current account deficits and the global deleveraging on credit growth have played a critical role, explaining the fact that Emerging Europe has experienced the greatest peak-to-through decline in quarterly real GDP.

\section{The ineffectiveness of monetary policy under fixed exchange rate regimes}

Macroeconomic and financial vulnerabilities deliver a clear message: countries having adopted fixed exchange rate regimes encountered important difficulties to respond to massive capital inflows before the global financial crisis.

On the one hand, as stressed above, despite an increasing positive output gap, higher capital inflows, and stronger credit boom, countries with fixed exchange rates had real short term interest rates lower than floaters (see figure 3). In other words, monetary policy has been more loosened in the first group of countries. Indeed, fixed exchange regimes constraint the ability of the central bank to raise its policy rates insofar as raising domestic rates may attract more capital flows and, in turn, induce a pressure on the exchange rate. In accordance with the impossible trinity, authorities cannot attain at the same time (i) a fixed exchange rate, (ii) an independent monetary policy, and (iii) free capital movements. The main point is that, within the context of European integration, many Emerging Europe countries have to ensure open financial account in order to respect rules defined in Copenhagen (the so-called "Copenhagen criteria") to be eligible to join the European Union. Peggers must face a conflict between the external constraint -the fixed exchange rate cannot appreciate- and internal constraints such as the control of domestic credit expansion.

On the other hand, peggers are reluctant to let their currency appreciate to curb capital inflows (figure 11). As a result, they lose a significant degree of freedom in the conduct of economic 
policy. More specifically, allowing the exchange rate to appreciate tends to slow capital inflows for the following reasons:

- nominal appreciation is equivalent to a tightening of monetary conditions that leads to lower inflation and growth expectations;

- as the domestic currency appreciates today, expectations of future appreciations decrease and, in turn, reduce prospective returns.

As a consequence, countries become less attractive for international investors.

\section{[Insert Figure 11]}

\section{The response of the monetary policy to Global financial crises}

Since Lehman Brothers collapse on September 15, 2008, Emerging Europe has been hit by two major shocks: the Global financial crisis from 2008 to 2009 and the European sovereign debt crisis since 2011.

\section{From the Global financial crisis to the European sovereign debt crisis}

Focusing on the financial channel, one of the main consequences of these shocks has been extremely severe tensions in the banking system. The left side of figure 12 exhibits tension on interbank funding markets while the right side shows the increase in the banking sector CDS spreads. On this figure, we estimate the spreads between the unsecured money market segment (EURIBOR) ${ }^{5}$ and the secured money market segment (EUREPO). ${ }^{6}$ As expected, we see that during the periods of intense financial stress, the spreads increase as banks lose confidence in their counterparties in the interbank market. The major episode of stress corresponds to Lehman Brothers collapse while the European sovereign debt crisis leads to two episodes, the first beginning in May 2010 with the Greek crisis and the second in 2012 with the contagion to Italy, Portugal, and Spain.

\section{[Insert Figure 12]}

The right side of figure 12 portrays the credit default swap spreads for the banking sector in the EU, the United Kingdom, and the United States. A credit default swap is a financial swap agreement in which an agent (the buyer) purchases from a counterparty (the seller) an insurance against the event of default or other credit events The CDS spread represents the premium paid by protection buyer to the seller. Thus, when the probability of default 
increases, it must result in a spread rise as many agents wish to protect against the occurrence of such defaults. As a result, insofar as the probability of defaults tends to increase during periods of major financial stress, we expect that CDS spreads are a good indicator of financial tensions. Figure 12 shows clearly that it is the case. All banks had been affected by Lehman Brothers collapse explaining the rise in banking sector CDS spreads in both the European Union, the United Kingdom, and the United States. If the European sovereign debt crisis seems to have only a limited impact on British and U.S. banks, figure 12 exhibits a dramatic increase for the European banking sector CDS spreads.

The major consequence of these tensions has been the bank deleveraging process at a worldwide level. Figure 13 exhibits this process for our sample countries. We can see a decrease in the external positions of reporting banks vis-à-vis all sectors in terms of 2013 GDP. The negative shock is particularly large in countries with fixed exchange rate regimes.

\section{[Insert Figure 13]}

A second significant consequence of the crisis is the presence of a financial shock transmission -in both directions- between the euro area and Emerging Europe. Figure 14 illustrates this transmission by exhibiting rolling correlations between CDS spreads in Emerging Europe and the European Union.

In figure 14, rolling correlations are portrayed for two financial variables.

The rolling correlation is widely used to assess a model's stability over time. Contrary to the simple statistical correlation analysis, we do not make the assumption that the economic environnement is constant over time. Considering two univariate time series $y_{1 t}$ and $y_{2 t}$ over the sample $t=1, \ldots T$, the rolling correlation between $y_{1 t}$ and $y_{2 t}$ is given by:

$$
\hat{\rho}_{12, t(n)}=\frac{\hat{\sigma}_{12, t(n)}}{\hat{\sigma}_{1, t(n)} \hat{\sigma}_{2, t(n)}}
$$

where $\hat{\sigma}_{12, t(n)}$ stands for the rolling covariance between $y_{1 t}$ and $y_{2 t}$ :

$$
\hat{\sigma}_{12, t(n)}=\frac{1}{n-1} \sum_{i=0}^{n-1}\left(y_{1 t-i}-\hat{\mu}_{1 t}(n)\right)\left(y_{2 t-i}-\hat{\mu}_{2 t}(n)\right)
$$

In this paper, we consider rolling correlation over $n=90$ days.

\section{[Insert Figure 14]}


The left side exhibits the rolling correlation between CDS sovereign debt for our sample countries and the weighted CDS sovereign debt for IIPS. Such indicator allows us to see to what extent sovereign debt crisis in the Euro area and crisis in Emerging Europe are interplayed. In the aftermath of Lehman Brothers failure, the correlation remained relatively low as the state of public finance in peripheral Europe was not a major cause for concerns. The situation changed dramatically with the Greek crisis. Two clusters of high correlation (we choose $\geq 0.60$ as arbitrary threshold) are identified. The first covers approximatively the period from March 2010 to March 2011. Interestingly, during this period, Granger causality tests suggest that CDS of our sample countries cause IIPS CDS. ${ }^{7}$ In other words, the deep recession in most of our studied economies seems to explain part of the increase in expected default of Ireland, Italy, Portugal, and Spain. The second episode refers to the period July 2011-September 2012, a period in which the Greek crisis spillovers to other peripheral European countries. During this period that corresponds to the peak in the European crisis, IIPS CDS Granger causes CDS in Emerging Europe. The right side of figure 14 exhibits rolling correlations between sovereign CDS of our studied countries and CDS of banking sector from the European Union. The correlation between the two variables has been particularly high, and widespread, from May 2010 to November 2010. Except Serbia, all correlations amount at least to 0.60 . Granger causality tests show that Baltics, economies are heavily dependent on external banking funds, are influenced by banking sector CDS. Indeed, a significant increase in banking CDS may lead to deleverage pressures on parent banks, then exerting tensions on countries with sizeable external or fiscal financing requirements.

\section{Monetary policy responses to the crisis ${ }^{8}$}

Interestingly, if many studies have provided new empirical evidence according to which emerging economies tend to adopt more frequently counter-cyclical policies to face crises today relatively to the 1990s' (Takáts, 2012; Vegh and Vuletin, 2012), Emerging Europe has remained largely out of this new policy framework.

Anecdotal evidences, based on countries experiences, suggest that peggers have been more constrained to respond to the crisis than floaters. Gardó and Martin (2010) show that policy stances differed across Central Eastern and South-Eastern European countries. Indeed, floaters countries tended to reduce their interest rates earlier (2008Q4) than fixers. Corozza et al (2011) consider the experience of South-Eastern European economies. As seen in previous papers, their striking result is that countries with hard pegs (Bosnia-Herzegovina and 
Montenegro) or conventional peg (Croatia and Macedonia) have been very constrained to use their monetary policy to face the global crisis. Thus, the National Bank of the Republic of Macedonia increased its interest rates in April 2009 (while the inflation rate decreased to zero) and the Croatian National Bank did not change its policy rates during the crisis. In a similar way, in the immediate aftermath of Lehman Brothers collapse, Hungary (and Russia too) increased their policy rates in October 2008 while Estonia and Lithuania did not change them. The Global financial crisis also suggests that countries with more room for lowering interest rates allowed more exchange rate depreciations.

Josifidis et al. (2013) has analyzed adjustment mechanisms for a sample of transition countries that acceded to the European Union in 2004, but stayed outside the euro area. Over the period 2004-2010, they find that countries with fixed exchange rate regimes have known a weakest real exchange rate adjustment in the aftermath of the Lehman collapse relative to other economies, limiting the ability of exchange rate to smooth negative external shocks. They also show that, when the real exchange rates change, it is the price level that adjusts in peggers while the nominal exchange rate moves in the floaters. As a result, real exchange rate adjustment tends to be very costly under fixed exchange rate regimes insofar as prices and wages are sticky.

Josifidis et al. (2014) study monetary policy responses to common financial shocks over the period 1995-2010 for a sample of ten emerging European countries by dividing the sample into two crisis periods (1995Q1-2001Q4 and 2002Q1-2010Q4). On the one hand, they find that common international financial shocks lead to different monetary policy responses. On the other hand, countries with high currency mismatch ratios suffer from both fear of floating and fear of losing international reserves. ${ }^{9}$ In other words, if the behavior of the short term interest rates is not significantly different during crisis periods between countries with high or low currency mismatch, it appears that the first group of countries are reluctant to depreciate their currency and / or loose foreign exchange reserves. These results are in line with the recent literature on Latin American countries stressing that the counter-cyclical monetary policy adopted during the Global financial crisis is in part explained by the dramatic decrease in the dollarization degree in the region (Cavallo and Izquierdo, 2009).

\section{The determinants of short term interest rates in Emerging Europe: the impact of domestic vulnerabilities and international factors}

The principal aim of this section is to assess the determination of short term interest rates in our studied countries. More specifically, by identifying the influence of potential determinants 
of interest rates, we see to what extent central banks are able to conduct an independent monetary policy.

\section{Tested regression}

Our dataset covers a time span period of 13 years, from 2001Q1 to 2013Q4, and encompasses the following countries: Bulgaria, Croatia, Estonia, Hungary, Latvia, Lithuania, Poland, Romania, and Serbia.

We test the following regression:

$i_{\text {domit }}=\alpha_{i}+\beta_{1}$ infl $l_{i t}+\beta_{2} O G_{i t}+\beta_{3} F L M_{i t}+\beta_{4} i_{e c b_{i t}}+\beta_{5}$ VSTOXX $_{i t}+\beta_{6}$ BIS eu $u_{i t}+$ $\beta_{7} E M B I G_{i t}+\beta_{8}\left(O G * D_{P e g}\right)_{i t}+\beta_{9}\left(i_{e c b} * D_{P e g}\right)_{i t}$

The dependent variable is $i_{d o m}$, the money market interest rate for each studied country (for $i=$ 1 to 9 ) at time $t \cdot{ }^{10} \mathrm{We}$ include 9 explanatory variables: the domestic inflation rate (infl), the domestic output gap $(O G)$, the foreign liabilities to money ratio (FLM) for FLM values above 100 , the Euro area money market rate as a proxy of the monetary policy interest rate $\left(i_{e c b}\right)$, the volatility index of the Euro Stoxx 50 (VSTOXX), the European banks' consolidated foreign claims of reporting banks - immediate borrower basis in percentage of domestic GDP (BIS $e u)$, the simple average of EMBIG spreads in the studied countries (EMBIG), and two interaction terms: $O G . D_{P e g}$ and $i_{e c b} . D_{P e g}$, with $D_{P e g}$ a dummy variable concerning countries with fixed exchange rate regimes over the studied period (Bulgaria; Croatia, Estonia, Latvia, and Lithuania). Domestic term refers to variables specific to each of our countries.

In order to estimate (3), we use the fixed effects transformation. If we consider a model with a single explanatory variable, then, for each $i$ :

$$
y_{i t}=\beta x_{i t}+a_{i}+u_{i t}
$$

for $t=1,2, \ldots T$. Now for each $i$, if we average this equation over time, we get:

$$
\overline{y_{i}}=\beta_{1} \overline{x_{i}}+a_{i}+\overline{u_{i}}
$$

where $\overline{y_{i}}=T^{-1} \Sigma_{t=1}^{T} y_{i t}$. We substract (5) from (4) so as to remove the unobserved effect $a_{i}$, and we find up with:

$$
y_{i t}-\overline{y_{i}}=\beta_{1}\left(x_{i t}-\overline{x_{i}}\right)+u_{i t}-\overline{u_{i}}
$$

for $t=1,2, \ldots T$, and where $y_{i t}-\overline{y_{i}}$ is the time demeaned data on $y$. This fixed effect transformation is also called the within transformation.

We applied both random effects estimator and fixed effects and test for statistically significant differences in the coefficients on the time varying explanatory variables. We implement the 
Hausman test. The idea is that one uses the random effect estimates unless the Hausman test rejects them. For both estimation, the Hausman test is rejected.

\section{Results}

Results are reported in table 1. Two sets of regression are considered. In the first, we investigate the potential determinants of the short-term interest rate over the whole period 2001Q1-2013Q4 (Column 2). In the second, we focus on the crisis period 2007Q1-2013Q4 so as to explore the potential changes due to the global financial crisis (Column 7).

\section{[Insert Table 1]}

The coefficient $\beta_{1}$ has the expected positive sign. In other words, a higher inflation rate leads to a rise in short-term interest rate. Such relationship is consistent with a standard Taylor rule. Interestingly, we see that the value of $\beta_{1}$ is lower in the crisis period. This lower coefficient may reflect, on the one hand, the dramatic decrease in inflation after 2010 and, on the other hand, the influence of the Euro area interest rate in the region (see below).

The coefficient relative to the output gap $\left(\beta_{2}\right)$ exhibits opposite signs between the whole period and the crisis period. More specifically, while we obtain a negative sign (- 0.23$)$ for the whole period, the sign becomes positive (0.14) during the crisis period. This finding highlights the ability of the studied countries to move towards a more active countercyclical policy in the aftermath of the crisis. The negative value of $\beta_{2}$ over the whole period is in line with the finding exhibited in figure 2. Indeed, the monetary policy has been relatively ineffective to respond to positive output gap before the global financial crisis. As stressed above, many of our studied countries have adopted a procyclical monetary policy during this period suggesting that a positive $\beta_{2}$ conveys a countercyclical policy. However, the interaction between the output gap and the dummy variable reflecting the adoption of fixed exchange rate regimes $\left(D_{P e g}\right)$ leads us to qualify this interpretation. Indeed, if the variable OG. $D_{P e g}$ has an insignificant coefficient $\left(\beta_{8}\right)$ on the whole period, we see that $\beta_{8}$ is statistically significant and negative (- 0.31$)$ over the crisis period. This result allows us to conclude that fixed exchange rate regimes exert an important constraint on the ability of the monetary policy to respond to negative shocks on the domestic output.

The coefficient concerning the FLM ratio $\left(\beta_{3}\right)$-used as a proxy of the degree of dollarization or currency mismatch- is insignificant over the whole period. This may mean that 
dollarization is not an important constraint for monetary policy in tranquil period. In contrast, over the period 2007-2013, not only $\beta_{3}$ is positive and statistically significant, but it exhibits a particular high value (0.52). Dollarization is clearly an impediment to conduct a monetary policy devoted to macroeconomic stabilization.

As the economic and financial integration is very high between our studied countries and the Euro area, it is important to see to what extent short term interest rates in the Euro area influence domestic interest rates in Emerging Europe. Table 1 shows that, whatever the considered period, $\beta_{4}$ is positive and particularly high (1.04 for the whole period and 0.65 for the crisis period). In other words, the conduct of domestic monetary policy is influenced by the policy adopted in the Euro area. When we interact the Euro area interest rate with the dummy variable $D_{P e g}$, we find that the Euro area interest rate exerts a stronger influence during the crisis period ( 0.69 for coefficient $\left.\beta_{9}\right)$. In a similar way, using a New Keynesian Phillips curve in an open economy framework, Iossifov and Podpiera (2014) find that, after controlling for different factors that affect the inflation process, pegger countries have been especially prone to import deflationary pressures from Euro area relative to floaters. As stressed by the authors, countries with flexible exchange rates have been able to benefit from easing cycle of monetary policies that lead to depreciating pressures on their currency.

The last three variables in table 1 are important to consider insofar as they allow us to assess the influence of external financial factors on domestic interest rates.

As the VIX index for the U.S. equity market, the VSTOXX index measures market expectations of near term volatility conveyed by stock index option prices. Since volatility often signifies financial turmoil, VSTOXX index is often referred to as the "investor fear gauge". The VSTOXX index tends to be high during times of financial turmoil and investor fear. During tranquil periods, VSTOXX index levels tend to drop. As a result, this index is an indicator of investor's perception of risk. Table 1 shows that $\beta_{5}$ is positive in the two periods without exhibiting a significant increase during the global financial crisis despite the increase in the risk perception in the aftermath of the Lehman Brothers collapse. In fact, figure 15 shows that the VSTOXX index reacts brutally and quickly to specific economic and financial tensions but does not remain at very high levels for a long time period. This behavior may account for our result.

\section{[Insert Figure 15]}


In the first section, we highlighted the increasing dependence of our country vis-à-vis external bank financing, particularly from European banks. In this perspective, it is interesting to assess how this dependence influences the determination of short-term interest rates. Table 1 shows that the ratio European banks' consolidated foreign claims of reporting banks over domestic GDP $\left(\beta_{6}\right)$ exerts a positive and significant impact for both periods, and increasing for the global financial crisis, moving from 0.02 to 0.04 . This is in line with the stronger financial vulnerability in Emerging Europe relative to other emerging regions.

The variable EMBIG measures yield spreads (over safe or risk free assets that bear minimal credit risk) on emerging market countries' debt instruments. The spread is the extra return required to compensate the investor for the additional risks faced when investing in emerging economies rather than in a safe asset (such as a US government bond). EMBIG measures the sovereign risk. Spreads increase with the deterioration -effective or expected- of fundamentals in the countries issuing bonds; they also increase in periods of international financial strains. As a result, EMBIG is a proxy for market and foreign investor sentiment and it also gauges contagion from global or other emerging markets crisis. As emerging European countries experience significant external vulnerabilities (see section 1), we expect that the coefficient relative to EMBIG $\left(\beta_{7}\right)$ is positive. More specifically, an increase in the EMBIG spread may lead to liquidity strains -e.g. net capital outflows- that are harmful for countries experiencing huge deficit current accounts. Table 1 confirms this relation for the crisis period, but the coefficient is small (0.005).

Overall, our results suggest that domestic and financial vulnerabilities matter to assess the ability of monetary policy to stabilize the economy in response to negative shocks.

\section{Conclusion}

This paper has investigated the conduct of monetary policy in a sample of nine emerging European countries over the period 2000-2013. Four findings are particularly important. First, we show that countries with fixed exchange rate regimes have encountered significant obstacles to conduct monetary policy to cope with large capital inflows and credit booms during the period preceding the financial crisis. Second, pegged countries have been more constrained to respond to the global financial crisis than non-pegged economies. Third, countries with high currency mismatch and financial vulnerabilities seem unable to adopt monetary policy dedicated only to macroeconomic stabilization. Finally, we find that interest rate in the Euro area is an important determinant of short term interest rate in our studied countries. 
The previous results raise the question of the adoption of the euro. Specifically, it is questionable whether membership in the Euro area could have avoided increasing vulnerabilities observed in 2000-2007. The experience of the peripheral Euro area countries suggests a negative answer. Indeed, the European Central Bank has not been able to respond efficiently to overheating affecting these countries. Similarly, constraints on exchange rate faced by Southern Euro area countries suggest that they are in a position close enough to the countries outside the euro zone with a high degree of currency mismatch. 


\section{References}

Aizenman, J. and Hutchison M. (2012). Exchange market pressure and absorption by international reserves: emerging markets and fear of reserve loss during the 2008-09 crisis. Journal of International Money and Finance, 31, 1076-1091.

Aizenman J. and Sun Y. (2012). The financial crisis and sizable international reserves depletion: from 'fear of floating' to the 'fear of losing international reserves?. International Review of Economics and Finance, 24, 250-269.

Allegret J.P. (2012). Responses of monetary authorities in emerging economies to international financial crises: What do we really know?. European Research Studies Journal, 15(3), 3-32.

Bakker, B. and Gulde A. (2010). The credit boom in the EU new member states: bad luck or bad policies?. IMF Working Paper, WP/10/130.

Balakrishnan R., Danninger S., Elekdag S. and Tytell I. (2011). The transmission of financial stress from advanced to emerging economies. Emerging Markets Finance and Trade, 47(03S2-May-June), 40-68.

Berkmen P., Gelos G., Rennhack R., and Walsh J.P. (2012). The global financial crisis: explaining cross-country differences in the output impact. Journal of International Money and Finance, 31(1), 42-59.

Bernanke B.S., Reinhart V.R. and Sack B.P. (2004). Monetary policy alternatives at the zero bound: an empirical assessment. Brookings Papers on Economic Activity, Economic Studies Program, The Brookings Institution, 35(2), 1-100.

Bubula A. and Ötker-Robe I. (2002). The evolution of exchange rate regimes since 1990: evidence from de facto policies. IMF Working Paper, WP/02/155.

Cavallo E. and Izquierdo A. (2009). Policy responses to sudden stops: a comparative analysis, in Dealing with an international credit crunch, policy responses to sudden stops in Latin 
America. Edited by E. Cavallo and A. Izquierdo, Inter-American Development Bank, Washington, D.C., 1-22.

Cocozza E., Colabella A., and Spadafora F. (2011). The impact of the global crisis on SouthEastern Europe. IMF Working Paper, WP/11/300, December.

Committee on the Global Financial System (2009). Capital flows and emerging market economies. CGFS Papers, 33, January.

Eichengreen B. and Hausmann R. (1999). Exchange rates and financial fragility, new challenges for monetary policy. A symposium sponsored by the Federal Reserve Bank of Kansas City, Jackson Hole, Wyoming, 329-368.

Eichengreen B., Hausmann R., and Panizza U. (2007). Currency mismatches, debt intolerance, and original sin: why they are not the same and why it matters, in Capital controls and capital flows in emerging economies: policies, practices and consequences. Edited by S. Edwards, NBER, University of Chicago Press, 121-169.

Forbes, K. and Warnock F. (2012). Capital flow waves: surges, stops, flight, and retrenchment. NBER Working Paper; ${ }^{\circ} 17351$.

Frankel J.A. and Saravelos G. (2012). Are leading indicators of financial crises useful for assessing country vulnerability? Evidence from the 2008-09 global crisis. Journal of International Economics, 87(2), 216-31.

Gallego S., Gardó S., Martin R., Molina L. and Serena J.M. (2010). The impact of the global economic and financial crisis on Central Eastern and Southeastern Europe (CESEE) and Latin America. Bank of Spain, Working Paper, 1002.

Ghosh A.R., Chamon M., Crowe C., Kim and Ostry J.D. (2009). Coping with the crisis: policy options for emerging market countries. IMF Staff Position Note, April, SPN/09/08. International Monetary Fund (2013). Spillover report-Analytical underpinnings and other background. IMF Policy Paper, August. 
International Monetary Fund (2010). How did emerging markets cope in the crisis?. Strategy, Policy, and Review Department, June, Washington D.C.

International Monetary Fund (2008). Europe, reassessing risks. Regional Economic Outlook, April.

Iossifov, P. and Podpiera J. (2014), Are non-Euro area EU countries importing low inflation from the Euro area?, IMF Working Paper, WP/14/191.

Josifidis K., Allegret J.P., and Becker-Pucar E. (2013). Adjustment mechanisms and exchange rate regimes in new 2004 EU members during the financial crisis. Post-Communist Economies, 25(1), 1-17.

Josifidis K. Allegret J.P., Gimet C., and Beker-Pucar E. (2014). Macroeconomic policy responses to financial crises in emerging European economies. Economic Modelling, 36(January), 577-591.

Kaminsky G.L. and Reinhart C.M. (1999). The twin crises: the causes of banking and balance-of-payments problems. The American Economic Review, 89(4), 473-500.

Kaminsky G.L., Reinhart C.M., and Végh C.A. (2005). When it rains, it pours: procyclical capital flows and macroeconomic policies. NBER Macroeconomic annual, edited by $\mathrm{M}$. Gertler and K. Rogoff, 11-82.

Lane P.R. and Milesi-Ferretti G.M. (2011). The cross-country incidence of the global crisis. IMF Economic Review, 59(1), 77-110.

Levy Yeyati E., Sturzenegger F., and Reggio I. (2010). On the endogeneity of exchange rate regimes. European Economic Review, 54(5), 659-677.

Llaudes R., Salman F., and Chivakul M. (2010). The impact of the great recession on emerging markets. IMF Working Paper, WP/10/237.

Magud, N., and Vesperoni E. (2014). Exchange rate flexibility and credit during capital inflow reversals: purgatory...not paradise. IMF Working Paper, WP/14/61. 
Mishkin F.S. (1997). The causes and propagation of financial instability: lessons for policymakers, in Maintaining financial stability in a global economy. A symposium sponsored by the Federal Reserve Bank of Kansas City, Jackson Hole, Wyoming, 55-96.

Reinhart C.M. and Rogoff K.S. (2004). The modern history of exchange rate arrangements: a reinterpretation. The Quarterly Journal of Economics, 119 (1), 1-48.

Takáts E. (2012). Countercyclical policies in emerging markets. BIS Quarterly Review, June, 25-31.

Vegh C.A. and Vuletin G. (2012). Overcoming the fear of free falling: monetary policy graduation in emerging markets. NBER Working Paper Series, No. 18175, June. 


\section{End-notes}

${ }^{1}$ This distinction is based on different de facto classifications. See Bubula and Ötker-Robe (2002), and Reinhart and Rogoff (2004).

${ }^{2}$ Once the zero lower bound is reached, the central banker cannot stimulate aggregate demand or stabilize financial markets through interest rates cuts. In this case, monetary policy becomes "unconventionnal". The central banker is then brought to use nonstandard measures, notably forward guidance, assets buyouts and longer term refinancing operations (but also collateral enlargement, decreases in reserve requirements, fixed rate and full allotment refinancing operations...). See Bernanke B.S. et al. (2004).

${ }^{3}$ See Appendix 1 for the definition of the output gap.

${ }^{4}$ See also Forbes and Warnock (2012).

${ }^{5}$ The Euro Interbank Offered Rate (Euribor) is the average interest rate for unsecured euro term deposits calculated from a panel of more than 30 contributing banks provide daily quotes of the highest rate offered by one prime bank to another for an unsecured euro term deposit.

${ }^{6}$ The Europe is the average interest rate for secured money market transactions in the euro area calculated from a panel of contributing banks providing daily quotes of the highest rate on the market offered by one prime bank to another for funds in euro in exchange for certain collateral.

${ }^{7}$ Broadly speaking, a variable $\mathrm{X}$ Granger-causes $\mathrm{Y}$ if $\mathrm{Y}$ can be better predicted using the histories of both $\mathrm{X}$ and $\mathrm{Y}$ than it can using the history of $\mathrm{Y}$ alone.

${ }^{8}$ This subsection draws heavily from Allegret (2012), Josifidis et al. (2013 and 2014).

${ }^{9}$ Based on fear of losing international reserves behavior, see Aizenman and Hutchison (2012) and Aizenman and Sun (2012).

${ }^{10}$ See Appendix 1 for data definitions and sources. 
Appendix 1 Data definitions and sources

\begin{tabular}{|c|c|c|}
\hline Variables & Definition & Source \\
\hline$i_{\text {dom }}$ & $\begin{array}{l}\text { Short term interest rate } \\
\text { Money market rates }\end{array}$ & Eurostat and IMF, International Financial Statistics \\
\hline infl & $\begin{array}{l}\text { Domestic inflation } \\
\text { Consumer price index, annual percentage change }\end{array}$ & IMF, International Financial Statistics \\
\hline$O G$ & $\begin{array}{l}\text { Output Gap } \\
\text { Cyclical part of the Hodrick-Prescott filter, difference between the GDP } \\
\text { and its long run counterpart, namely the trend }\end{array}$ & IMF, International Financial Statistics \\
\hline FLM & $\begin{array}{l}\text { Foreign liabilities to money ratio } \\
\text { Foreign liabilities 26C [Liabilities to Non-residents FOSLF] / (Reserve } \\
\text { money } 14 \text { [Monetary base FASMB] + Demand deposits } 24 \text { [Transferable } \\
\text { deposits included in broad money FOST]). Concepts in brackets refer to } \\
\text { new IMF codes. }\end{array}$ & IMF, International Financial Statistics \\
\hline$i_{e c b}$ & Euro area money market rate & Eurostat \\
\hline VSTOXX & Volatility indices, Euro area equity market, Euro STOXX 50 & Macrobond \\
\hline BIS eu & $\begin{array}{l}\text { European banks' consolidated foreign claims of reporting banks - } \\
\text { immediate borrower basis over domestic GDP ratio }\end{array}$ & $\begin{array}{l}\text { Bank for International Settlements and IMF, } \\
\text { International Financial Statistics }\end{array}$ \\
\hline$E M B I G$ & $\begin{array}{l}\text { J.P. Morgan Emerging Markets Bond Index Global } \\
\text { Spread between sovereign bonds in emerging markets and comparable } \\
\text { United States Treasuries Simple average of the sample countries }\end{array}$ & Macrobond \\
\hline$O G . D_{P e g}$ & $\begin{array}{l}\text { Interaction between the output gap }(\mathrm{OG}) \text { and pegged exchange rate regimes } \\
\text { (currency board, conventional peg, and crawl-like arrangement) }\end{array}$ & IMF, International Financial Statistics \\
\hline$i_{e c b} . D_{P e g}$ & $\begin{array}{l}\text { Interaction between the Euro are money market rate and pegged } \\
\text { exchange rate regimes (currency board, conventional peg, and crawl- } \\
\text { like arrangement) }\end{array}$ & Eurostat \\
\hline
\end{tabular}




\section{Tables}

Table 1 Interest rates determinants in Emerging Europe

\begin{tabular}{|c|c|c|c|c|c|c|}
\hline \multirow[b]{2}{*}{ Variables } & \multicolumn{3}{|c|}{ 2001Q1-2013Q4 } & \multicolumn{3}{|c|}{ 2007Q1-2013Q4 } \\
\hline & Coefficients & t-student & (p-value) & Coefficients & t-student & (p-value) \\
\hline Constant & -0.42 & 0.53 & 0.59 & -0.29 & -0.36 & 0.71 \\
\hline Inflation $\left[\beta_{1}\right]$ & $0.74 * * *$ & 5.83 & 0.00 & $0.17 * * *$ & 3.31 & 0.00 \\
\hline$O G\left[\beta_{2}\right]$ & $-0.23 * * *$ & -2.99 & 0.00 & $0.14^{*}$ & 1.74 & 0.08 \\
\hline$F L M\left[\beta_{3}\right]$ & -0.05 & -0.12 & 0.90 & $0.52^{* * *}$ & 2.37 & 0.00 \\
\hline$i_{e c b}\left[\beta_{4}\right]$ & $1.04 * * *$ & 3.32 & 0.00 & $0.65^{* * *}$ & 5.17 & 0.00 \\
\hline VSTOXX $\left[\beta_{5}\right]$ & $0.02 * *$ & 2.53 & 0.01 & $0.05 * *$ & 2.46 & 0.01 \\
\hline BIS еи $\left[\beta_{6}\right]$ & $0.02 * * *$ & 2.75 & 0.00 & $0.04 *$ & 1.80 & 0.07 \\
\hline$E M B I G\left[\beta_{7}\right]$ & 0.001 & 0.94 & 0.34 & $0.005 * * *$ & 4.40 & 0.00 \\
\hline$O G . D_{P e g}\left[\beta_{8}\right]$ & -0.07 & -0.95 & 0.33 & $-0.31 * * *$ & -3.71 & 0.00 \\
\hline$i_{e c b} . D_{P e g}\left[\beta_{9}\right]$ & -0.45 & -0.99 & 0.32 & $0.69^{* * *}$ & 3.77 & 0.00 \\
\hline
\end{tabular}

Notes: Robust standard errors, $* * * \mathrm{p}<0.01,{ }^{*} * \mathrm{p}<0.05, * \mathrm{p}<0.1$ 

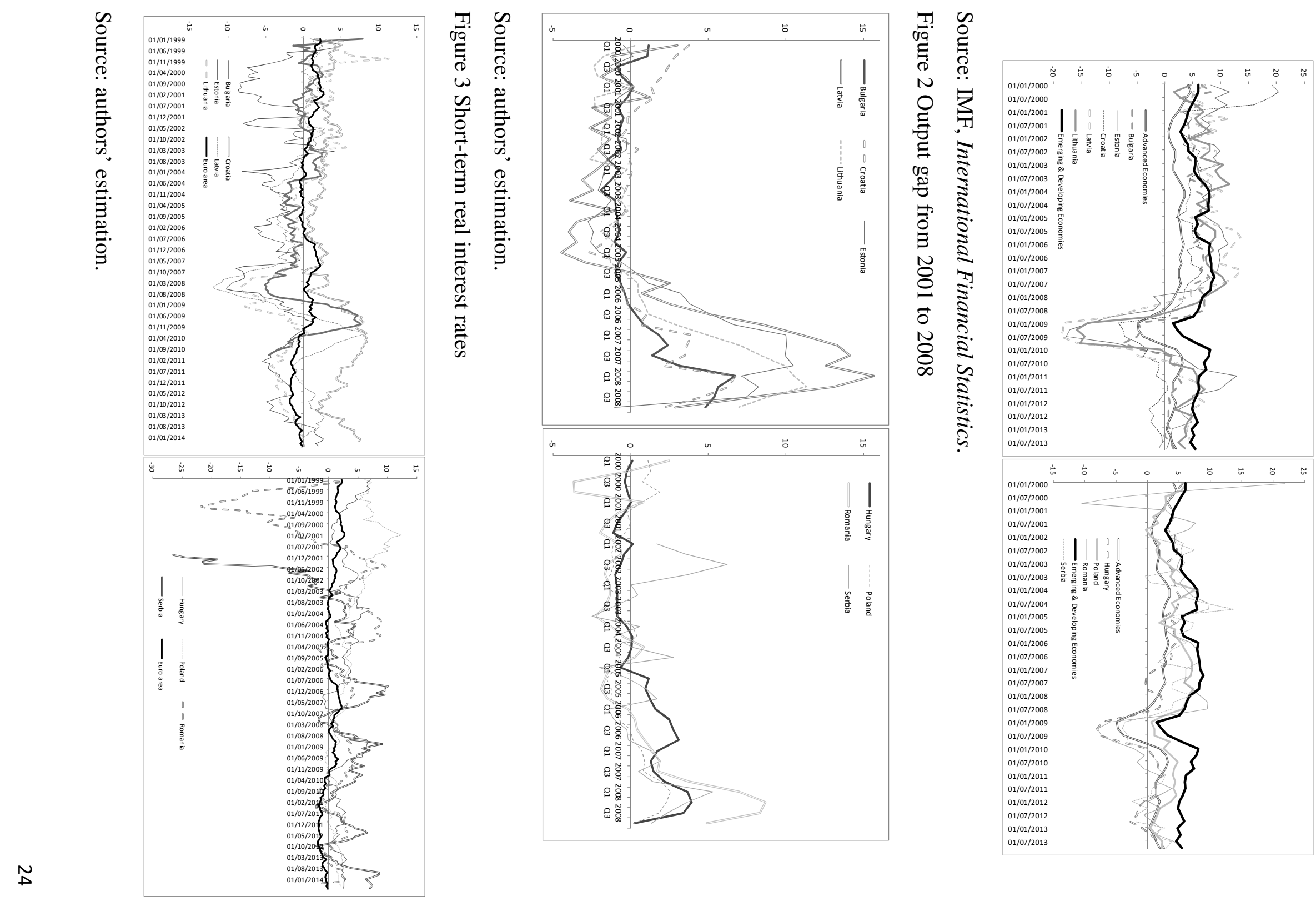

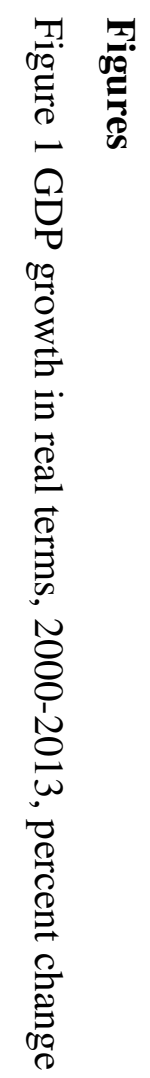


Figure 4 Indicators of credit boom

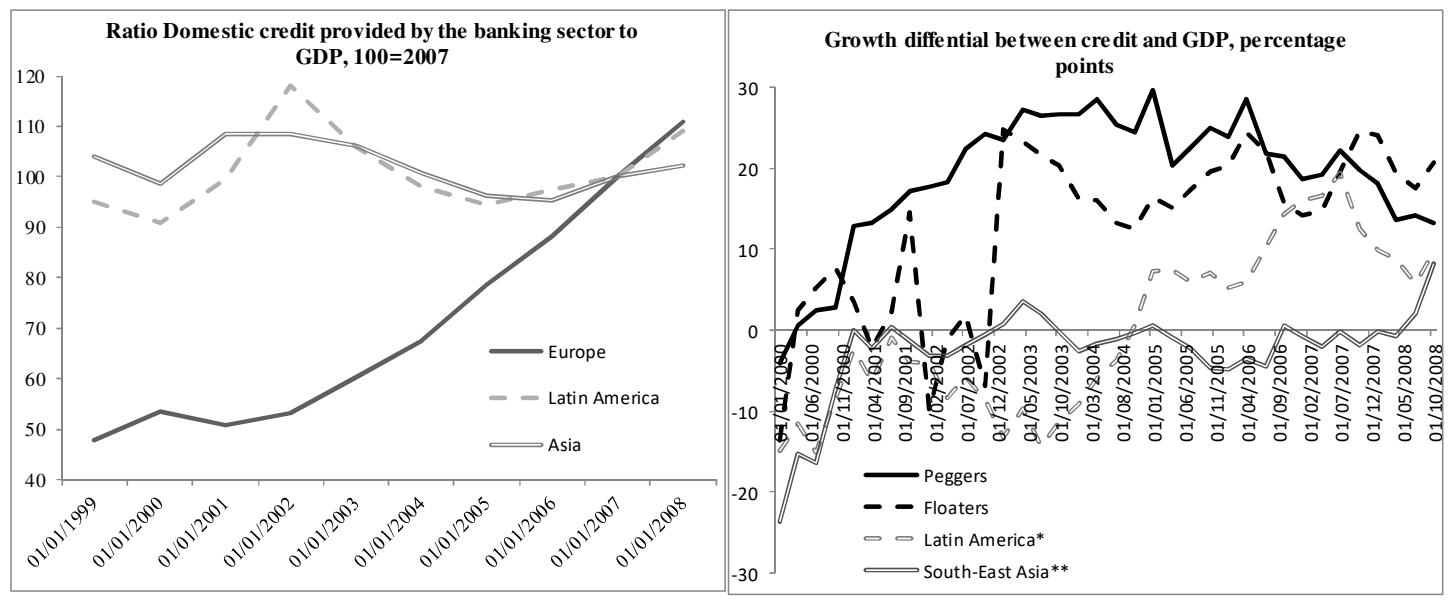

* Argentina, Brazil, Chile, Mexico, and Colombia, simple average.

** Indonesia, Malaysia, Philippines, South Korea, and Thailand, simple average.

Sources: authors' estimations. Data extracted from World Bank, World Development Indicators, and IMF, International Financial Statistics.

Figure 5 Financial vulnerabilities increasing in Emerging Europe

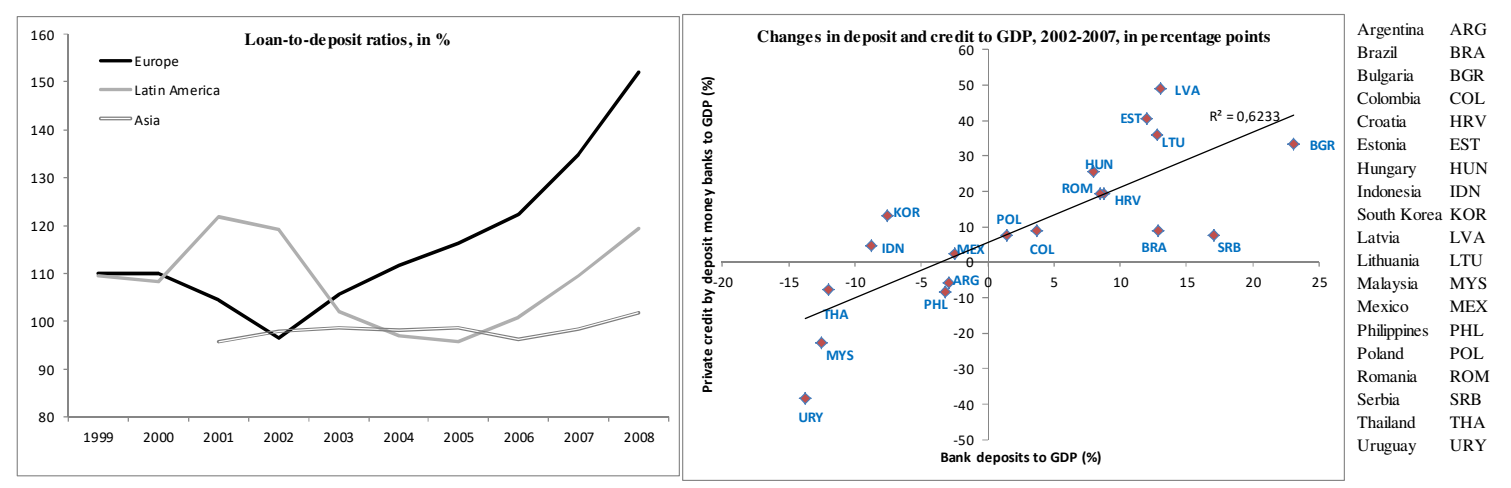

Sources: World Bank, Global Financial Development Database and authors' estimates.

Figure 6 External positions of reporting banks vis-à-vis all sectors, March $2007=100$

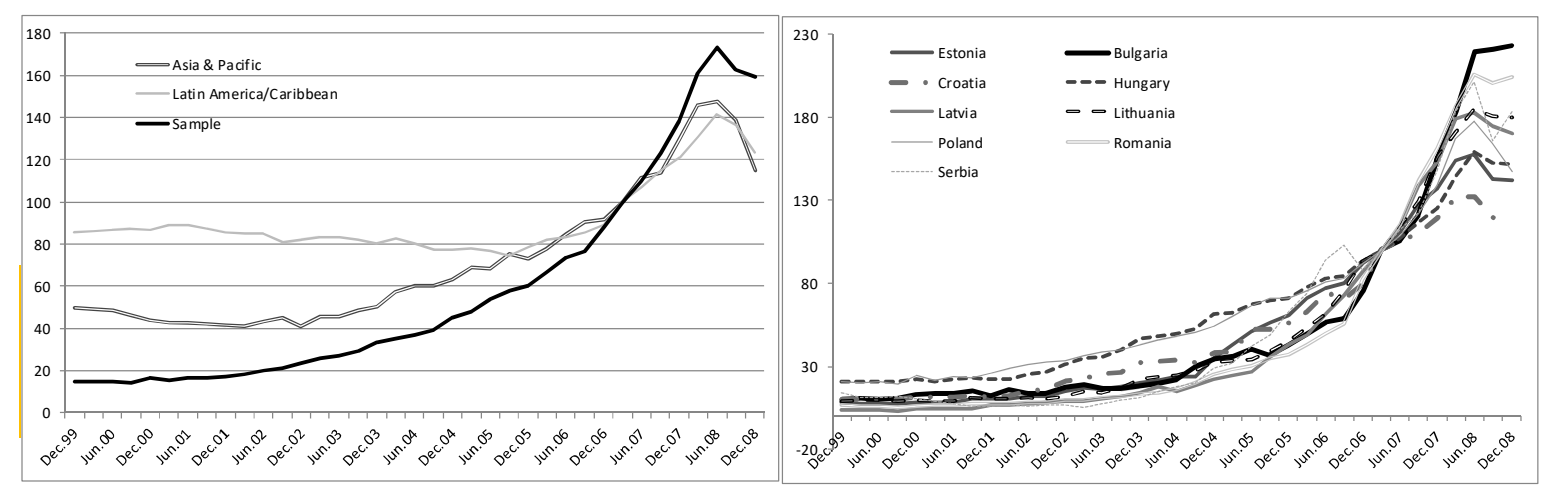

Source: authors' estimations. Data extracted from BIS, Locational banking statistics. 
Figure 7 Capital flows and credit expansion

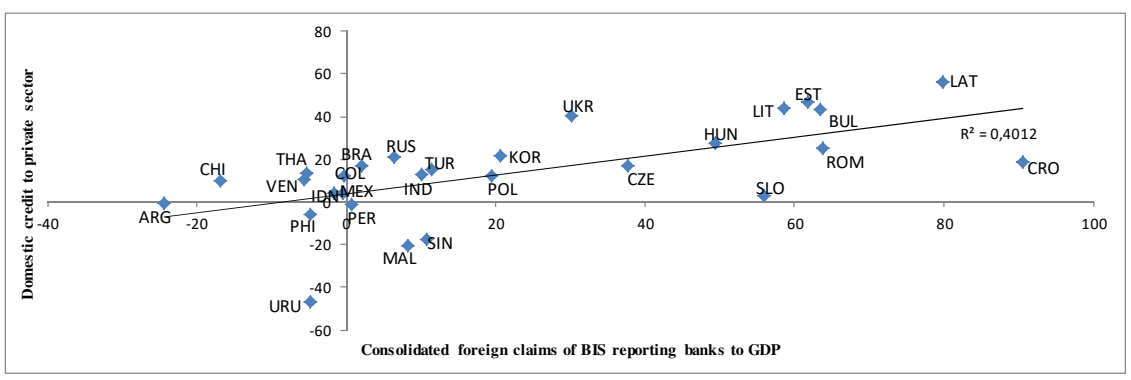

$\begin{array}{llll}\text { Argentina } & \text { ARG } & \text { Malaysia } & \text { MYS } \\ \text { Brazil } & \text { BRA } & \text { Mexico } & \text { MEX } \\ \text { Bulgaria } & \text { BGR } & \text { Peru } & \text { PER } \\ \text { Chile } & \text { CHL } & \text { Philippines } & \text { PHL } \\ \text { Colombia } & \text { COL } & \text { Poland } & \text { POL } \\ \text { Croatia } & \text { HRV } & \text { Romania } & \text { ROM } \\ \text { Czech Rep. } & \text { CZE } & \text { Russia } & \text { RUS } \\ \text { Estonia } & \text { EST } & \text { Singapore } & \text { SGP } \\ \text { Hungary } & \text { HUN } & \text { Slovakia } & \text { SVK } \\ \text { India } & \text { IND } & \text { Thailand } & \text { THA } \\ \text { Indonesia } & \text { IDN } & \text { Turkey } & \text { TUR } \\ \text { South Korea KOR } & \text { Urraine } & \text { UKR } \\ \text { Latvia } & \text { LVA } & \text { Uruguay } & \text { URY } \\ \text { Lithuania } & \text { LTU } & \text { Venezuela } & \text { VEN }\end{array}$

Source: authors' estimates. Data extracted from World Bank, Global Financial Development Database.

Figure 8 Ratio of Foreign Liabilities to Money in several emerging countries*, in \%

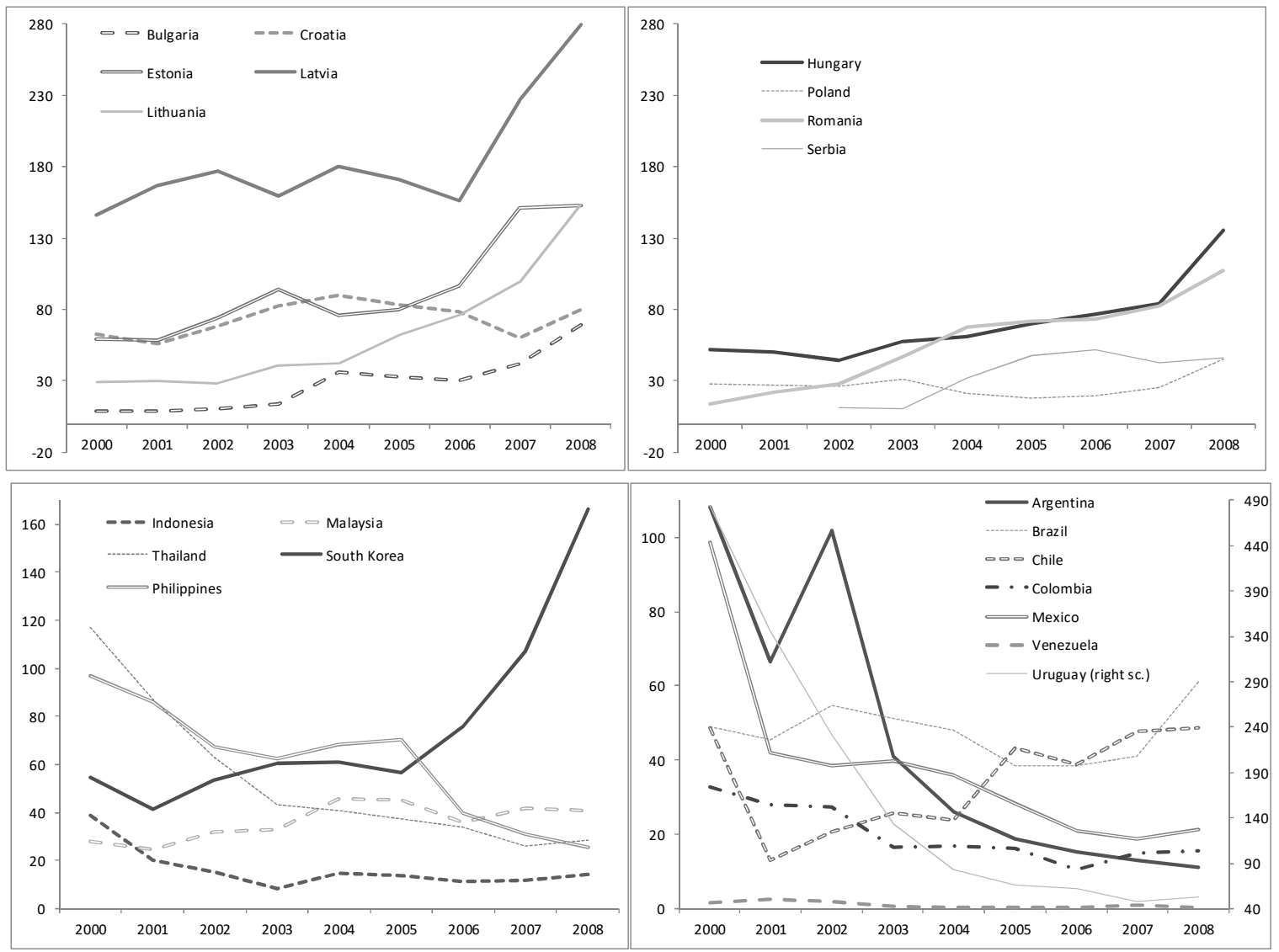

* See Appendix 1 for the definition of this variable.

Source: authors' estimates. Data extracted from IMF, International Financial Statistics. 
Figure 9 Current account balances in percentage of GDP
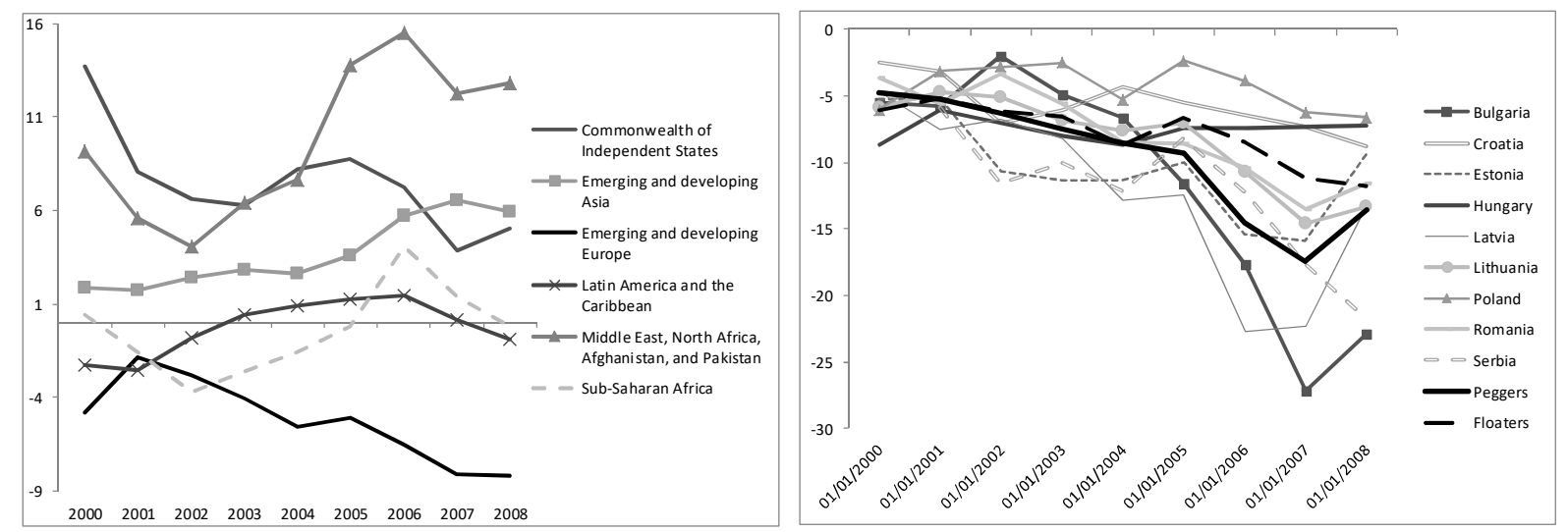

Source: IMF, World Economic Outlook Database.

Figure 10 Private capital flows, net, in U.S. dollars billions

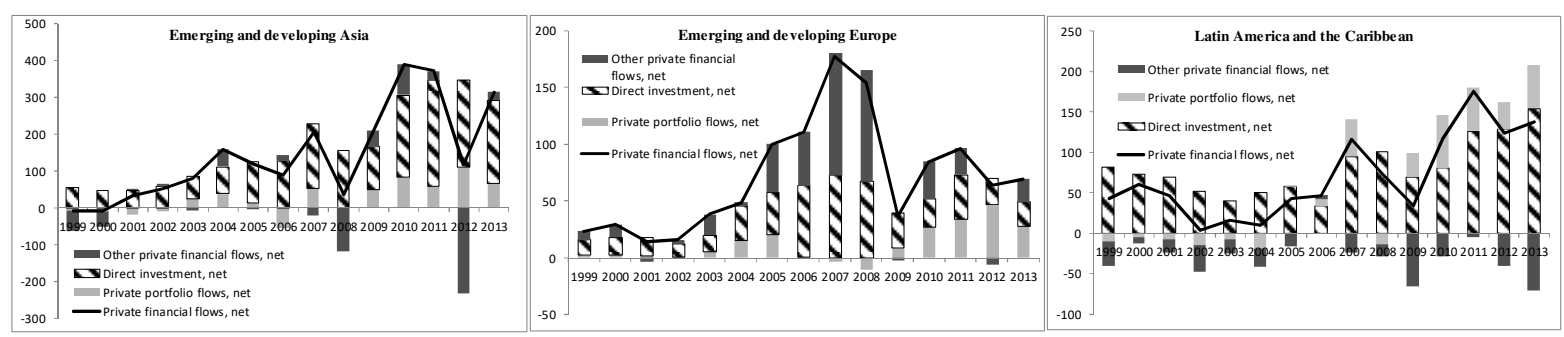

Source: IMF, World Economic Outlook Database.

Figure 11 Nominal effective exchange rates, $100=2010$

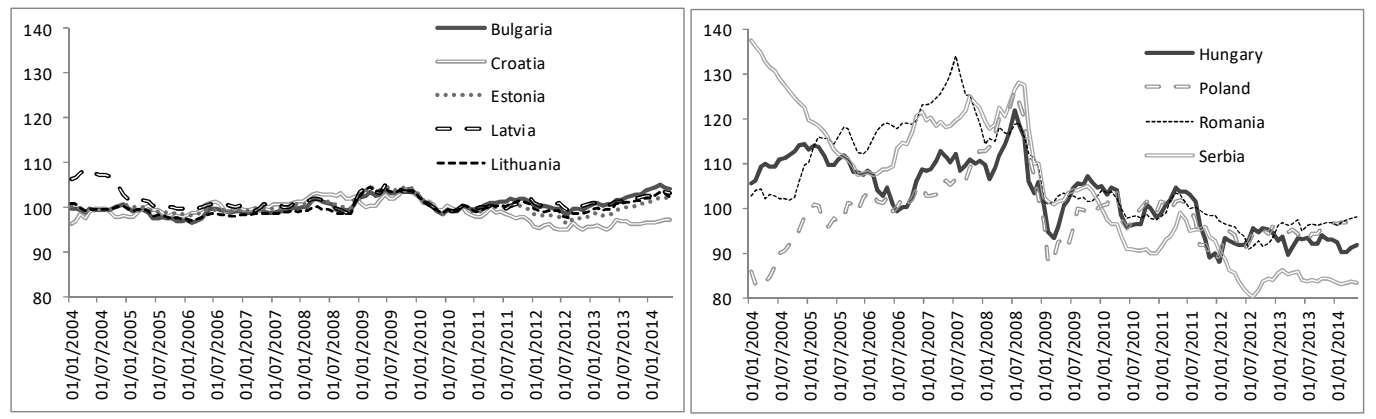

Source: Bank for International Settlements. 
Figure 12 Indicators of banking tensions

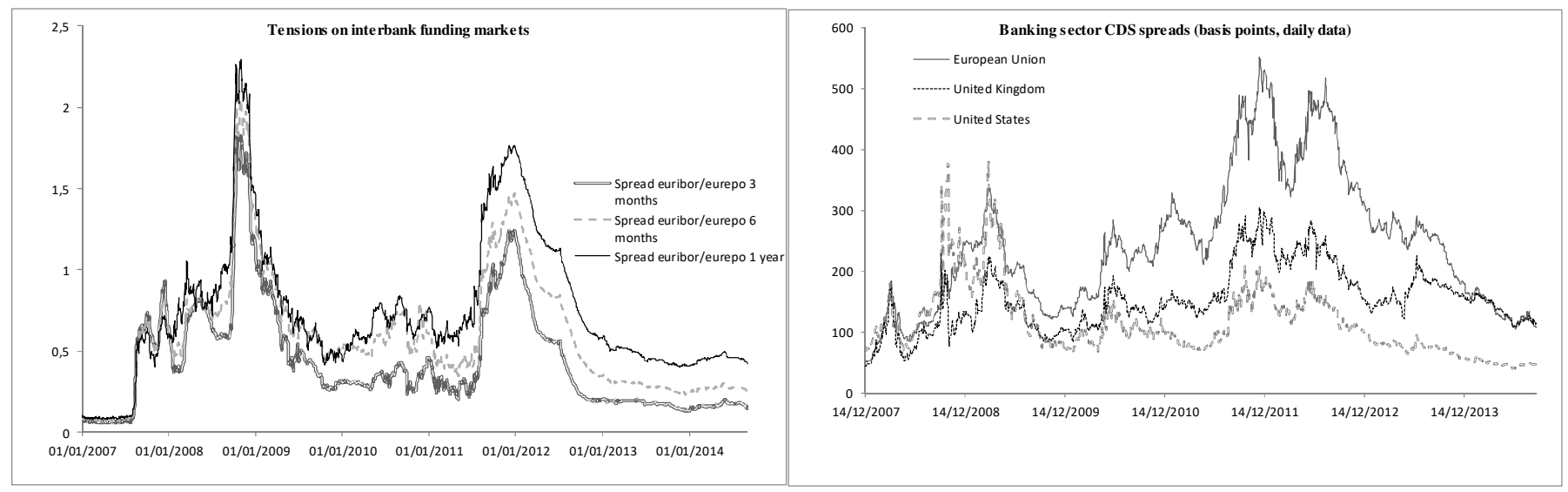

Sources: Macrobond and Datastream.

Figure 13 Changes in external positions of reporting banks vis-à-vis all sectors, in terms of 2013 GDP

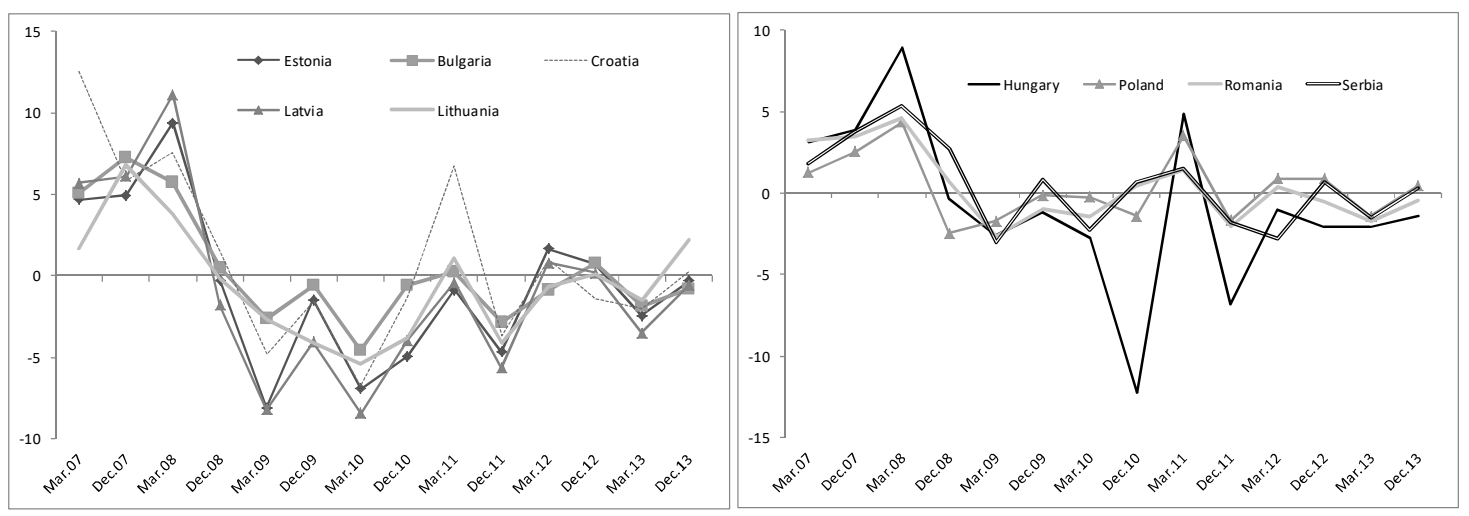

Source: authors' estimates. Data extracted from Bank for International Settlements. 
Figure 14 Rolling correlations between CDS spreads in Emerging Europe, CDS sovereign debt in IIPS*, and European Union banks CDS

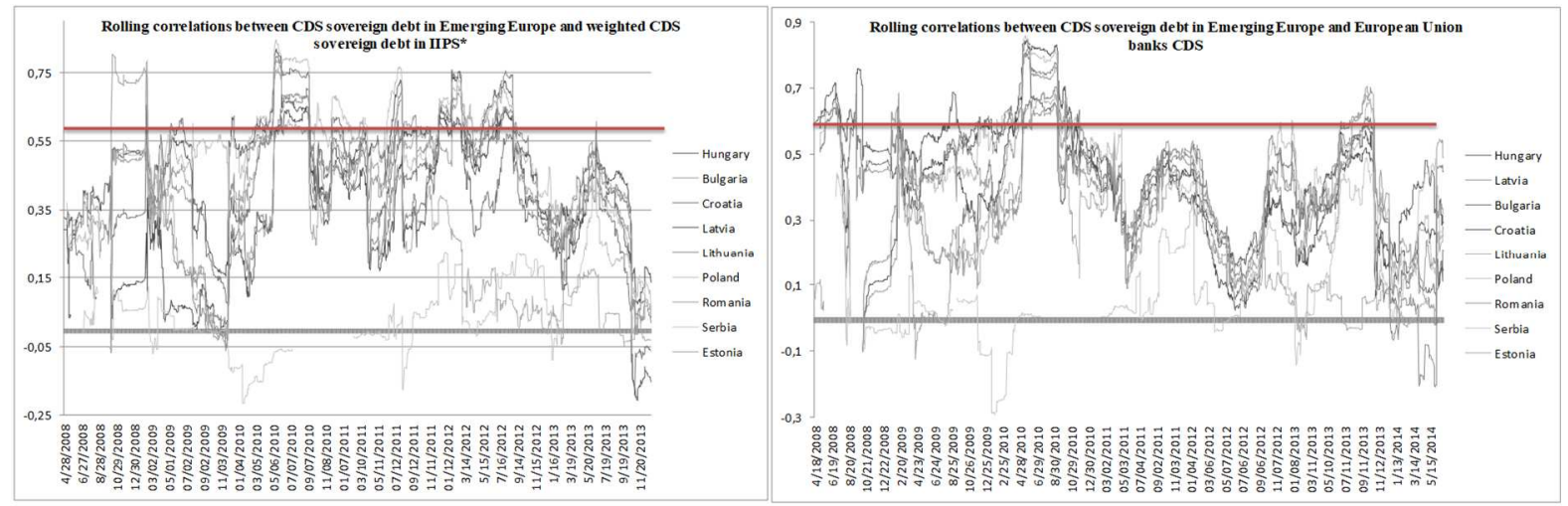

* To calculate the weighted CDS sovereign debt for Ireland, Italy, Portugal, and Spain (IIPS), we use the share of each domestic gross public debt in the total gross public debt of the Euro area. Data are extracted from the Eurostate database.

Source: authors' estimates. Data extracted from Datastream and Eurostate.

Figure 15 The VSTOXX Index, daily and quarterly data

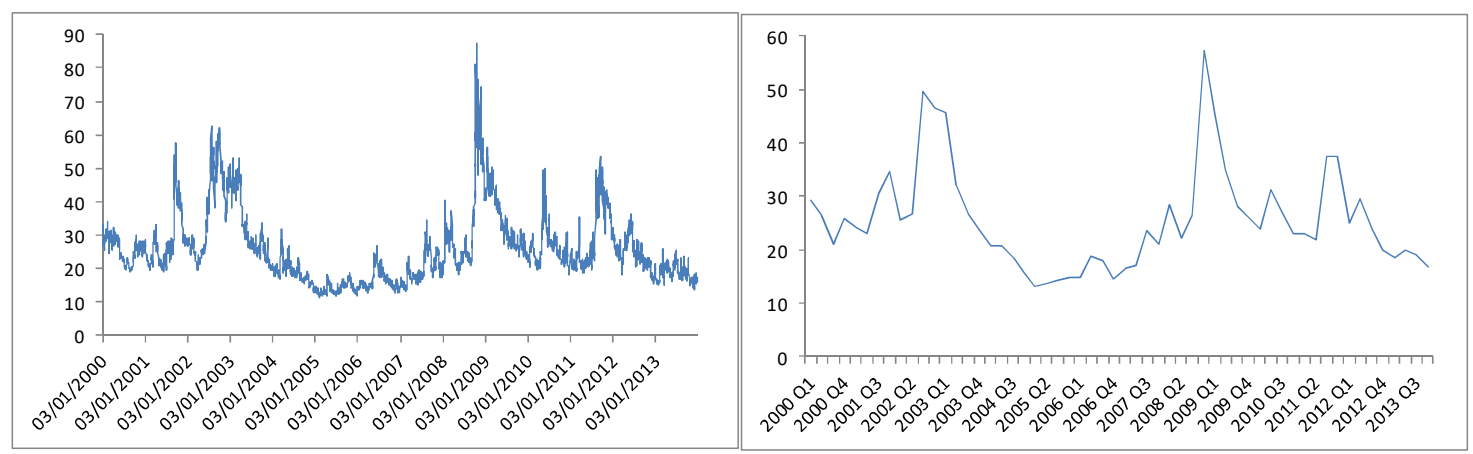

Source: Macrobond. 